Bull. Gronlands geol. Unders. 116, 5-9 (1975)

\title{
The crystal habit of naujakasite \\ with a note on some new occurrences
}

\section{Ole V. Petersen and Steen Andersen}

\begin{abstract}
The crystal forms of naujakasite, as determined on the two circle goniometer, are $\{001\},\{110\}$ and $\{\overline{1} 11\}$.

New occurrences of naujakasite of three different types are described: (1) accessory naujakasite in arfvedsonite-lujavrite, (2) a naujakasite-rich variety of lujavrite with exceptionally large crystals, (3) naujakasite formed by recrystallisation of naujaite.
\end{abstract}

\section{Introduction}

Naujakasite was first described by Bøggild (1933) from a loose boulder collected by Flink in 1897 at Naujakasik on the south coast of the fjord Tunugdliarfik, South Greenland. Naujakasite was found in outcrop in the summer of 1955 in the bay of Tuperssuatsiait on the south coast of Tunugdliarfik, and in 1956 it was also found on Kvanefjeld on the north side of the fjord (Danø \& Sørensen, 1959). A complete redescription was published by Petersen (1967) based mainly on a large number of specimens collected in 1964 at Tuperssuatsiait and Kvanefjeld. In 1972 S. Andersen found a number of new outcrops of naujakasite one of which yielded a limited number of crystals suitable for measurements on the two circle goniometer.

\section{Habit}

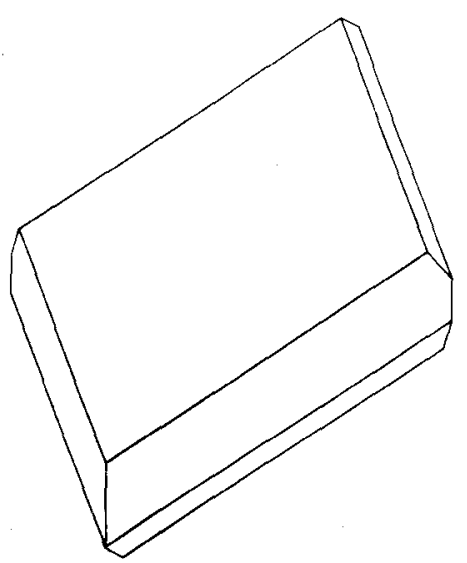

Fig. 1. Drawing of an idealised naujakasite crystal. 
The characteristic rhomb shaped crystals of naujakasite were described in 1964 on the material then available. The crystals were not suitable for quantitative determination of the developed forms. Since then crystals have been found in gravel weathered out of the lujavrite at a locality about $1 \mathrm{~km}$ south-east of Tuperssuatsiait.

The rhomb-shaped crystals are about $20 \times 10 \times 5 \mathrm{~mm}$ in size (i.e. considerably larger than the crystals described by Petersen (1967)) with unregular $\{001\}$ cleavage faces, and eight plane but dull $\{\mathrm{hkl}\}$ faces which were non-reflecting. Thin plates of glass were therefore mounted on the faces. An idealised crystal is given as fig. 1 .

The measurements were plotted on a stereographic projection with (001) in the centre of the projection. After rotation $23.67^{\circ}\left(\beta\right.$ as determined by $\mathrm{X}$-ray $\left.=90.00^{\circ}\right)$ around the perpendicular to the symmetry plane of all the poles of the faces measured, the stereogram was compared with a stereogram constructed on the basis of the unit cell constants of naujakasite, i.e. $a_{0}=15.039 \AA, b_{0}=7.991 \AA, c_{0}=10.487 \AA$ and $\beta=113.67^{\circ}$ (Petersen, 1967) and the forms present, identified as $\{110\}$ and $\{\overline{1} 11\}$ in addition to $\{001\}$.

\section{Occurrences}

During detailed mapping in the southern part of the Ilímaussaq intrusion in the summer of 1972 a number of new occurrences of naujakasite were found near hill 435 about $1 \mathrm{~km}$ south-east of the classic locality at the bay of Tuperssuatsiait (Petersen, 1967).

The host rock at this locality is the so-called 'lujavrite-breccia' composed of blocks of naujaite of varying sizes separated by sheets and veins of lujavrite. The breccia forms a transitional zone between the massive naujaite to the north and west and a large sheet of arfvedsonite lujavrite to the south. (A general description of the rock types is found in e.g. Ferguson, 1970).

Within the breccia, naujakasite is found in three different settings:

(1) naujakasite is a widespread accessory mineral in the main arfvedsonite lujavrite. The distribution seems to be erratic and the content of naujakasite may vary from several per cent to nil in a single vein.

(2) A very naujakasite-rich variety of lujavrite has been observed as contact facies and as lenticular inclusions in normal lujavrite on the flanks of hill 435. The exceptionally large crystals from this rock type have been used for the goniometric work. (3) Composite flakes of naujakasite occur in a recrystallised naujaite at a single locality. This is the first time that naujakasite has been found in rocks other than lujavrite.

Details of the two last-mentioned settings are given below.

\section{The naujakasite-rich variety of lujavrite}

The naujakasite-rich rock has been found at two localities on the north-western and southern slopes of hill 435. The rock type is the same at the two localities although the setting is somewhat different. 
To the north-west of hill 435 the naujakasite-rich lujavrite can be followed for approximately $100 \mathrm{~m}$ in a narrow zone $75 \mathrm{~cm}$ wide along a contact between a major naujaite body and a later intrusion of arfvedsonite lujavrite. The zone strikes $080^{\circ}$ and is nearly vertical. The contacts against both the naujaite and the lujavrite are sharp. The marginal naujaite is recrystallised. The lujavrite contains small rhomb shaped crystals of naujakasite in accessory amount $(\sim 1 \%)$. The pronounced lamination of the lujavrite is parallel to the contact for a couple of metres, but farther away it makes a gentle bend to the general NW-SE strike with a low to moderate dip. Two elongated inclusions of recrystallised naujaite are found in the lujavrite just below a little rise a few metres from the contact. The dark, but weathered, lujavritic rock between these inclusions is rich in large crystals of naujakasite. A smaller $(10 \times 30 \mathrm{~cm})$ naujaite inclusion nearby is also surrounded by a naujakasite-rich zone.

On the southern flank of hill 435 the naujakasite-rich rock forms a number of rafts in a thick sheet of lujavrite varying from a few decimetres up to $50 \mathrm{~m}$ in length but with a constant width of 20 to $50 \mathrm{~cm}$. One of the rafts seems to be associated with a contact between naujaite and lujavrite. The rest appear to float in the lujavrite and are arranged parallel to the lamination, which is about $\mathrm{E}-\mathrm{W}$ with a moderate northerly dip.

The naujakasite-bearing rocks from the two localities are similar in mineralogy and texture (GGU No. 149402, 149405 and 149421, and 149483 respectively). They consist of closely packed crystals of naujakasite in a dense, black groundmass with a brownish to violet tint. The crystals of naujakasite amount to about $75 \%$ of the rock. Their average size is about $5 \mathrm{~mm}$ with $10 \times 20 \mathrm{~mm}$ as a maximum. The crystals have rhomb shaped outlines against the groundmass but become anhedral where they abutt each other. Steenstrupine (with pleochroic haloes) and arfvedsonite are common inclusions together with less frequent crystals of feldspar and aegirine. In some of the naujakasite crystals a heavy alteration to pigmentated analcime has taken place.

The groundmass bears strong similarity to the normal arfvedsonite lujavrite. The main minerals are microcline, albite and arfvedsonite, possibly with a slightly higher content of arfvedsonite than in the normal lujavrites. The lath-shaped alkali feldspars show a flowstructure, which swirls in between the naujakasite crystals. Arfvedsonite is interstitial. Stout prisms of aegirine are found in all sections. They grow independent of the flow structure and are therefore probably of late origin. Irregular masses of analcime are common and may also be late. In one of the specimens a network of fine analcime veins cross both naujakasite and the groundmass, resembling the well-known incipient replacement of olivine by serpentine.

The main difference between the groundmass of the naujakasite-rich rock and the normal arfvedsonite lujavrite is in the grain size, which is considerably smaller in the former. This is well illustrated in one section taken across the boundary between the two rock types (GGU No. 149483). On the lujavrite side of the very sharp contact the size of the feldspars is approximately $0.4 \times 0.1 \mathrm{~mm}$ in contrast to $0.08 \times 0.02 \mathrm{~mm}$ in the groundmass of the naujakasite-rich rock.

At the contact the tightly swirling flow-structure of the naujakasite-rich rock gives way to gently undulations. The large feldspars in the lujavrite follow the contact, but after a couple of millimetres all traces of whirls are lost. A few large crystals of naujakasite cross the contact to jut into the lujavrite. These features leave the impression that the lujavrite has swept over the contact of the inclusions and smoothed the irregularities away. 


\section{Naujakasite in naujaite}

Platy crystals of naujakasite have been found in recrystallised naujaite at the northern end of a small lake approximately $300 \mathrm{~m}$ south of hill 435 . The recrystallisation of the naujaite and the, probably contemporaneous, formation of the naujakasite are caused by the intrusion of a vein of arfvedsonite lujavrite, which is a few metres thick. The lujavrite is rich in light schlieren ascribed to deformed naujaite inclusions. Locally it contains small crystals of naujakasite.

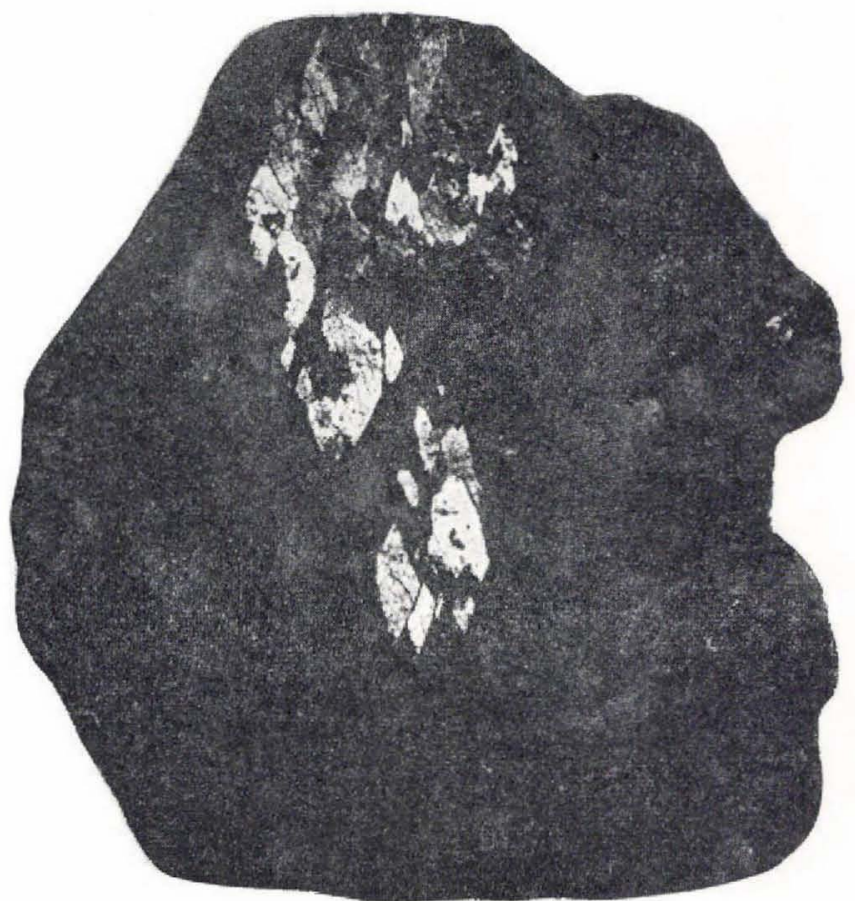

Fig. 2. Recrystallised naujaite with an aggregate of naujakasite rhombs in subparallel orientation. Double natural size. GGU' no. 149480. P. Nielsen photo.

In the recrystallised naujaite the characteristic poikilitic texture is still visible in the intergrowth of light and dark minerals, although the original arfvedsonite is almost totally recrystallised to aegirine, and euhedral sodalite is missing. The main light minerals are microcline and nepheline. The large crystals of microcline often enclose nepheline, which is found as equidimensional crystals with a tendency to develop hexagonal cross-sections. Nepheline, and, to a lesser extent, microcline may be replaced by analcime, sometimes associated with small laths of albite. Small euhedral crystals of pectolite are common.

The naujakasite is found in the recrystallised naujaite in a zone about one metre wide close to the lujavrite vein. It forms aggregates up to $5 \mathrm{~cm}$ in size composed of a number of smaller, rhomb shaped crystals in nearly identical orientation separated by the host material (fig. 2). The flakes of naujakasite seem to be superposed on the original texture of the recrystallised naujaite, which is retained between the single rhombs (fig. 3). The naujakasite as an inter- 


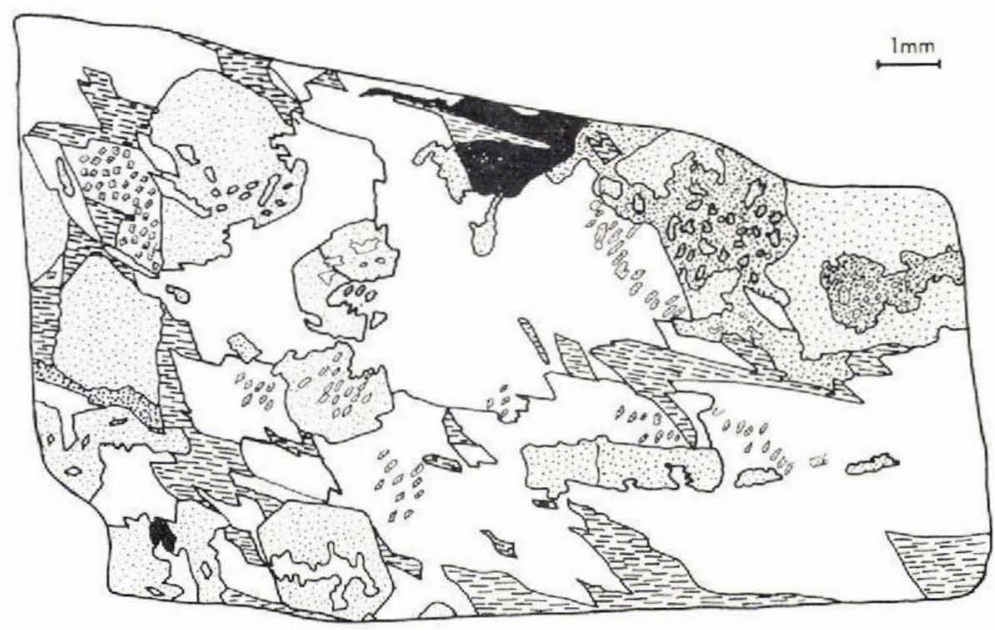

Fig. 3. Sketch of thin section no. 149480. Naujakasite, clear; microcline, ruled; nepheline, lightly stippled; analcime, heavily stippled.

growth with microcline and nepheline respectively is, however, different. The interstitial microcline has a wedge-like form with straight and very sharp boundaries against the naujakasite while naujakasite against nepheline has an irregular form and small patches of nepheline are enclosed in the naujakasite. A hexagonal outline may still be visible in the pattern of the nepheline inclusions.

\section{Acknowledgements}

The material was collected during the investigations in the Ilimaussaq intrusion under the direction of Professor H. Sørensen for The Geological Survey of Greenland.

Thanks are also due to Mrs. R. Larsen, who drew figure one, and Dr. C. K. Brooks, who kindly corrected the English of the manuscript.

\section{References}

Bøggild, O. B. 1933: Igalikite and naujakasite, two new minerals from South Greenland. Meddr Gronland 92, 9 [naujakasite, 7-12].

Danø, M. \& Sørensen, H. 1959: An examination of some rare minerals from the nepheline syenite of South West Greenland. Bull. Gronlands geol. Unders. 20 (also Meddr Gronland 162, 5) 36 pp.

Ferguson, J. 1970: The significance of the kakortokite in the evolution of the Ilimaussaq intrusion, South Greenland. Bull. Gronlands geol. Unders, 89 (also Meddr Gronland 190, 1) 193 pp.

Petersen, O. V. 1967: The mineralogy of naujakasite. Bull. Gronlands geol. Unders. 75 $^{\text {I }}$ (also Meddr Gronland 181, 6) 18 pp. 